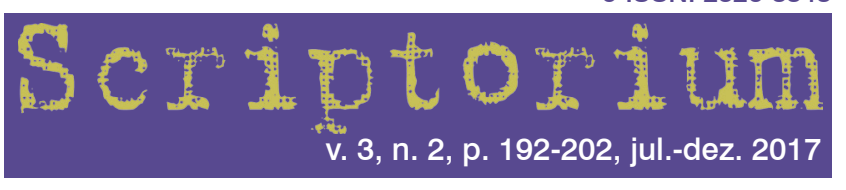

doi" http://dx.doi.org/10.15448/2526-8848.2017.2.29180

\title{
Olhar, memória, imaginário em Sebastião Salgado
}

\author{
View, memory, imaginary in Sebastião Salgado
}

\author{
PAULO MAIA* \\ Universidade Federal do Rio de Janeiro, Rio de Janeiro, RJ, Brasil
}

\begin{abstract}
Resumo: Este artigo busca compreender a transformação do olhar, da memória e do imaginário na fotografia de Sebastião Salgado em sua fotografia documental dos anos 1970 até 2000. Sentimento de travessia é uma formulação para o olhar, as memórias e o imaginário do fotógrafo sobre as novas morfologias no mundo do trabalho no período pós-industrial. Outras Américas (1986), seu primeiro ensaio publicado em livro, apresenta o problema do êxodo rural. Seu olhar sobre o tema, no entanto, é ainda incerto. Muito distante da idealização do primeiro ensaio, o livro Êxodos é uma síntese das transformações operadas no planeta a partir da nova morfologia do trabalho no final do século XX. Se em Outras Américas a travessia é contemplativa, em Êxodos a travessia é a força que orienta a transformação numa realidade marcada pela combinação de concentração de riquezas e inanição da classe trabalhadora.

Palavras-chave: Sebastião Salgado; narrativas fotográficas; sentimento de travessia.
\end{abstract}

\begin{abstract}
This paper seeks to understand the transformation of the look, of the memory, and of the imaginary in the Sebastião Salgado' documentary photography from $70^{\prime}$ s to 2000 's. Crossing feeling (sentimento de travessia) is a formulation about the view, memories and the imaginary of the photographer on the new morphologies in the world of work during the post-industrial period. Outras Américas, his first essay published as a book, presents the problem of the rural exodus, however, his look on the subject is still uncertain. Far away the idealization of the first essay, the book Exxodos is a synthesis of transformations happened in the world from the new morphology of the work at the end of the $20^{\text {th }}$ century. Although, in Outras Américas the crossing is contemplative, in Exxodos, the crossing is the power which guides the transformation in a reality marked by the combinations of the concentration of wealth and starvation of the working class.
\end{abstract}

Keywords: Sebastião Salgado; photographic narratives; crossing feeling.

Minha história percebida como rumor, sem palavras, sem voz, mas incorporada inteira, sólida. Na verdade ela é assim. A nossa imagem no mundo é a soma dos rumores, dos passos que demos e dos que não andamos, passaram por nós. Não há álibi nem conserto para a história que fica sendo nossa.

BEATRIZ BRACHER

\footnotetext{
* Doutor em Literatura Comparada pela UFRJ. Professor de Teoria Literária e Literatura Comparada na UFRJ.
} 
Este artigo busca compreender a transformação do olhar, da memória e do imaginário na fotografia de Sebastião Salgado. Sua fotografia documental a partir dos anos 60 demonstra uma perspectiva comprometida com as camadas populares da periferia do capital. Seu procedimento fotográfico, que o afasta do fotojornalismo, o conduz a um gênero narrativo conhecido como documental humanista, para o qual, o fotógrafo deve dispender um longo tempo para a produção. Fenômeno fotográfico é como Sebastião chama a convivência que estabelece com as comunidades que fotografa desde que partiu para um autoexílio durante a ditadura militar no Brasil. Ao longo de suas viagens por mais de 40 países, ele registrou transformações geopolíticas e geoculturais, mobilizadas pelo que o cientista social Ricardo Antunes chama de "nova morfologia do trabalho" e por consequências dessa metamorfose operada na era da produção manual, como migrações forçadas gerando uma enorme quantidade de refugiados em diferentes territórios no planeta. Exxodos (2000) é um ensaio que engloba os três anteriores, numa pesquisa que durou vinte e três anos (1977 a 2000): Outras Américas (1986), Trabalhadores: uma arqueologia da era industrial (1996) e Terra (1997).

Neste processo, sua perspectiva política se intensificou, suas memórias foram atravessadas com as urgências daqueles que fotografou, seu olhar trocou um tom de observação passiva dos problemas evocados por outro tom cuja forma propõe resistência e luta. Há um sentimento de travessia em cada imagem de Salgado na sua trajetória. Suas fotos demonstram a curiosidade do estudante, a atenção do antropólogo e o esforço de todos os trabalhadores com quem conviveu. Sentimento de travessia é o acúmulo das experiências de Salgado. Não há álibi nem conserto para a história que ficou sendo sua. Uma consciência da história, um inventário de imagens que evocam a transformação no planeta e na subjetividade do próprio fotógrafo, um imaginário sem palavras nem voz.

\section{Olhar}

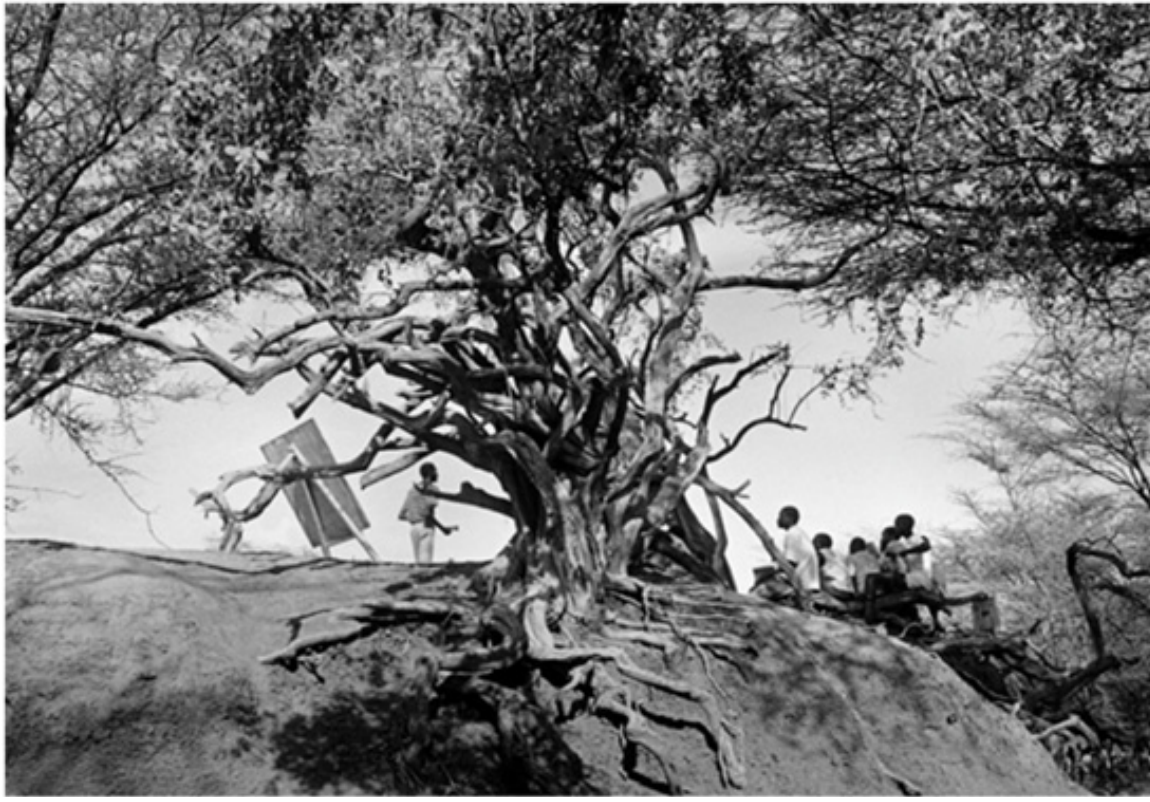

Figura 1. Exxodos, 2000. Campo de refugiados no Quênia. Guerra Civil no Sudão 1994

Que tipo de imaginação desperta uma imagem como esta? Sob árvores, há um quadro de anotações e um homem em pé com um apagador na mão. Seu olhar estabelece uma linha que se liga aos olhares de jovens sentados à sua frente. Ele parece falar coisas muito importantes para esses 
ouvintes atentos. É uma aula. No primeiro plano da imagem, uma árvore enraíza-se num barranco e divide a cena em duas partes, como uma balança. Unidade, equilíbrio e harmonia. Professor e alunos em uma composição cuja harmonia se dá no contraste entre as posições ocupadas na cena. Assim, há uma única e enraizada direção sintonizada para a transmissão do conhecimento. Além disso, a tranquilidade conotada pela imagem dos gestos do professor e a atenção concentrada dos alunos conferem uma tensão que sustenta o conjunto.

Os símbolos são tão fortes que mesmo sem legenda é fácil chegar a este sentido. Entretanto, se poderia olhar para a imagem e também imaginar um miliciano dando instruções a jovens forçados a lutar na guerra civil no Sudão no início dos anos 90. Tanto estado quanto milícias recrutavam sumariamente jovens em diferentes regiões do país para forçá-los ao combate. Isso obrigava muitos a fugirem para os países vizinhos, para campos de refugiados da ONU como este retratado acima, onde jovens sudaneses tem aula de acordo com o currículo do Quênia. Tal como nos informa a legenda preparada por Sebastião Salgado em seu livro Êxodos (2000).

A fotografia isola os indivíduos, estetiza o objeto, naturaliza a experiência. Sebastião Salgado convive intensamente com seus fotografados e suas fotografias resultam do acordo estabelecido. O fotógrafo produz imagens do nosso tempo, seus princípios políticos e todos os outros que dão forma às suas composições remontam estratégias clássicas. Suas obras são alegorias épicas que remetem a transformações radicais de nossa natureza no fim do século XX. O tema é fundamental, o livro denuncia mobilizações forçadas em massa, identificando grupos de refugiados em todos os continentes. "Fenômeno fotográfico" é como Salgado chama seu procedimento de investigação, negociação e produção fotográfica. É um momento único, um instantâneo construído com muita delicadeza e atenção pelo seu olhar.

A informação sobre a utilização do currículo do Quênia e a formatação que analisamos acima, no entanto, sugerem uma cultura desativada, pois tornada refém, tornada passiva. A legenda de Salgado ainda nos informa que muitas comunidades do Sudão eram seminômades até alguns anos antes da produção do ensaio fotográfico. Sendo assim, deviam também ter outras formas de organização do trabalho e da educação, outras culturas desautorizadas pela guerra. Ao fugirem do autoritarismo do estado e das milícias, estes jovens são salvos em abrigos no país vizinho, o Quênia. É importante que tenham sido recebidos e que tenham tido acesso a algum tipo de educação formal. Do contrário, estariam ainda mais perdidos em suas culturas de origem, completamente devastadas. É necessário, contudo, observar a ideologia que parece atravessar a experiência registrada no olhar do fotógrafo e como isso passa a também atravessar o nosso imaginário. A imagem documenta uma aula e isso não é difícil identificarmos.

Haverá outras interpretações da imagem; porém, a legenda deve ocupar um papel modalizador (SONTAG, Sobre a fotografia, 1977). O eixo dos olhares em diagonal, a posição de destaque do professor e do quadro com informações na composição da foto e a legenda estabelecem um padrão de comunicação em canal fechado. O problema não está no conteúdo da imagem, mas na forma da experiência representada. A forma, 
discreta ou ostensivamente, será ela mesma o verdadeiro conteúdo da relação estabelecida entre os sujeitos retratados. Verdadeiro não é irrefutável. Por isso, há formas variadas de trabalho e comunicação, assim como há todo tipo de autonomia e liberdade. Os jovens sudaneses, nesse caso, fugiram de um território perigoso, de um espaço hostil e opressor, para conquistar autonomia. Isso se analisarmos a questão sob uma perspectiva idealista e teleológica, desconsiderando que caça e caçador tem esperanças simultâneas. Sob outro prisma, entretanto, podemos questionar: estes jovens estariam aprendendo mais do que ouvir e observar? Parece que não, parece que aprendem a obedecer e reproduzir. E nós com eles, pois é tal imaginação que uma imagem como esta desperta em nosso imaginário.

\section{Memória}

Êxodos (2000) conta a história das migrações forçadas, dos refugiados e exilados por razões bélicas, sanitárias e econômicas no final do século $X X$ em diferentes regiões da periferia do capital. O fotógrafo percorreu diferentes lugares, atravessou diversas culturas e foi atravessado pelo impasse comum que as aproximava.

Este livro conta a história da humanidade em trânsito. É uma história perturbadora, pois poucas pessoas abandonam a terra natal por vontade própria. Em geral, elas se tornam migrantes, refugiadas ou exiladas constrangidas por forças que não têm como controlar, fugindo da pobreza, da repressão ou das guerras. Partem com os pertences que conseguem carregar, avançam como podem a bordo de frágeis embarcações, espremidas em trens e caminhões, a pé... Viajam sozinhas, com as famílias ou em grupos. Algumas sabem pra onde estão indo, confiantes de que as espera uma vida melhor. Outras estão simplesmente em fuga, aliviadas por estarem vivas. Muitas não conseguirão chegar a lugar nenhum (SALGADO, Exodos, p. 9).
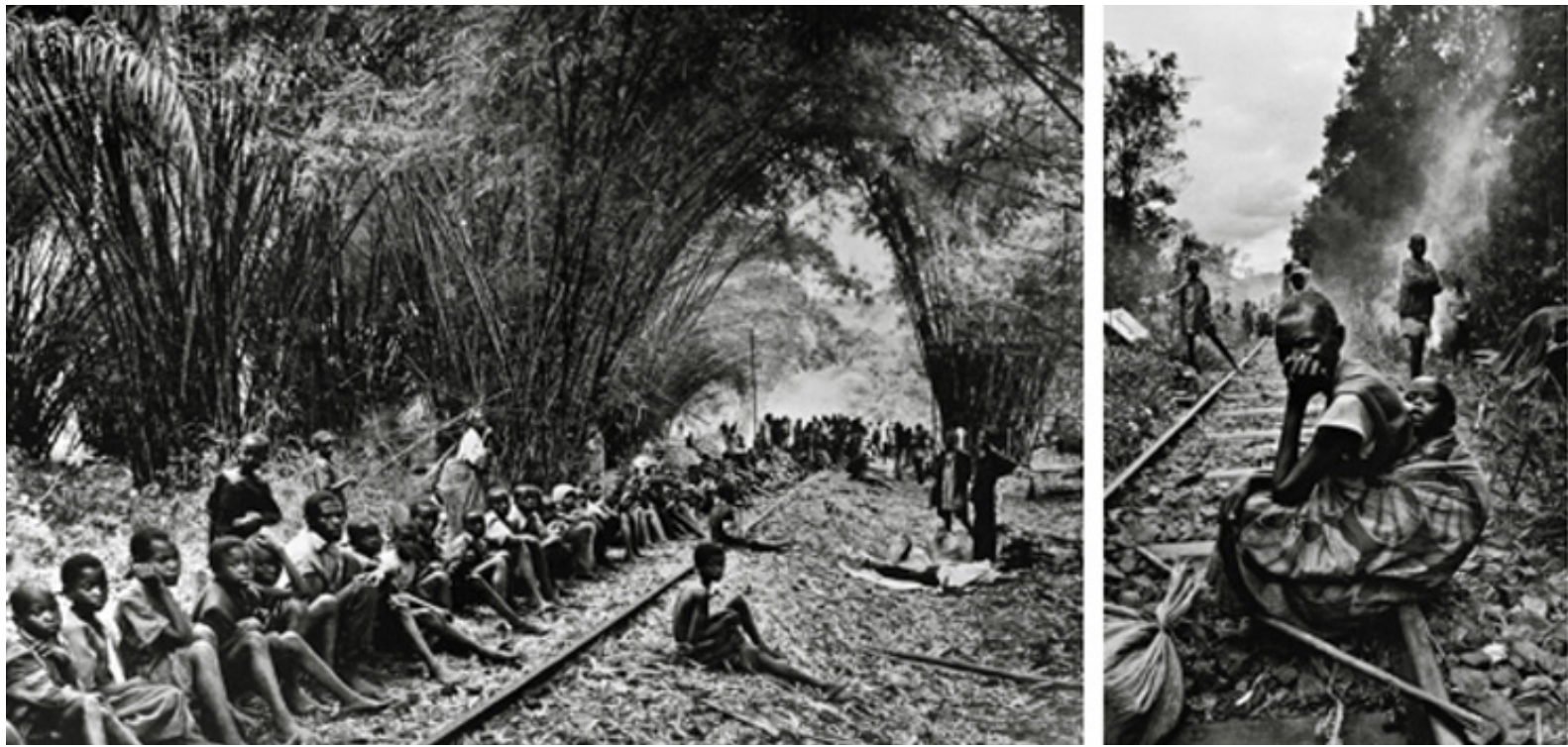

Figuras 2 e 3. Êxodos, 2000. República Democrática do Congo, 1997. 
A fotografia de Salgado é fruto de um sentimento, na medida em que ele afirma a vivência que recria em seus retratos. Sentimento de travessia poderia ser o modo como reconhecemos o seu procedimento. Há um percurso realizado, um tempo vivido e, sobretudo, memórias atravessadas no processo de construção de suas narrativas fotográficas. Memórias de um narrador viajante e, de certa forma, também migrante, já que ele mesmo se autoexilara do Brasil depois do golpe militar em 1964.

Nos anos 1990, uma guerra civil paralisou o Sudão, tirou o país do trilho da história, ou destinou a ele um lugar especialíssimo fora da locomotiva do progresso. Por fim, milhares de sudaneses foram obrigados a fugir para países vizinhos, como a República Democrática do Congo. Sebastião Salgado estava na África para fotografar a experiência dos médicos sem fronteira no combate à poliomielite e foi envolvido por diferentes conflitos civis.

A perspectiva e o autocontraste nas imagens deste ensaio despertam memórias insólitas. A silhueta funciona como uma evidência da partida. As linhas do trilho dão profundidade e volume ao conjunto, equilibrando a composição e alargando a dimensão da tragédia. Salgado viaja ao contexto dos conflitos para documentar as movimentações populacionais forçadas no continente. $O$ fotógrafo reelabora suas memórias da experiência vivida com imagens de um colecionador de fragmentos de um mundo partido. Sob este aspecto, podemos aproveitar a perspectiva sobre memória que Walter Benjamin desenvolve em $O$ narrador.

O filósofo divide em duas categorias o que chama de narrador clássico, aquele que tiraria da memória a sua legitimidade. O narrador agricultor sedentário seria um artesão local que nunca saiu de sua comunidade e, por isso, teria uma visão detalhada da experiência social e da tradição do grupo ali reunido, a qual tem o compromisso de repassar às novas gerações. $\mathrm{O}$ narrador marinheiro, ou viajante, por outro lado, seria aquele que deve passar por muitos lugares diferentes e trazer ao seu grupo de origem uma visão fragmentária de diferentes lugares e culturas diversas visitados. Um contribuiria para a manutenção da tradição necessária à reprodução da vida daquela comunidade; o outro traria de diferentes povos as novidades técnicas e culturais que contribuíssem para a renovação. O primeiro seria responsável pela conservação de sua comunidade, o segundo pela sua modernização. Os dois seriam necessários ao enriquecimento da tradição a que se vinculavam como narradores clássicos. Mesmo que eles não existam mais objetivamente, seus traços permanecem em alguns narradores, como Sebastião Salgado, um narrador que narra com seu olhar, com suas memórias, com seu imaginário.

As narrativas de Salgado apresentam alguns desses traços. Ele pode ser associado com um narrador marinheiro, que aprendeu muito com os narradores locais, os agricultores, no curso de suas viagens. Se o adjetivo "marinheiro" se aplica somente como metáfora a Salgado, o sentimento de travessia que se aprofunda nos seus projetos fotográficos até Êxodos atinge, neste ensaio, um limite trágico. Êxodo, termo bíblico referente à expulsão de um povo de suas terras, daquelas que Ihes teriam sido "prometidas", será mais adiante uma intensificação da síntese formal proposta já em Outras Américas, o seu primeiro ensaio, realizado nos anos 70 . O sentimento de travessia marca intensamente a estética e a missão autodeclarada nos projetos de 
Salgado. Em Êxodos, entretanto, o fotógrafo aprofunda o debate sobre o trânsito do "homem em desespero" apontando a ele uma direção necessária de resistência e emancipação.

Ao mostrar os marginalizados na América Latina, na África e em outros lugares do planeta as suas travessias, as migrações forçadas, o êxodo, o fotógrafo relaciona esses movimentos com as contradições no mundo do trabalho. No final do século $\mathrm{XX}$, a transformação das forças produtivas e a mundialização do capital impõem uma dura realidade para os trabalhadores, cada vez mais explorados, desagregados e despojados de sua tradição, de sua cultura e autonomia. Os homens e mulheres fotografados por Salgado ou estão encurralados ou em fuga sem destino certo. Os ensaios fotográficos de Salgado revelam a ele próprio que a principal desagregação causada pela expansão do capital atingiu principalmente o mundo do trabalho. Progressivamente, suas narrativas organizam as memórias da desagregação, as observadas e as do observador, e alegorizam o mundo, tornando-o símbolo da derrota. Ricardo Antunes chama este processo histórico de uma nova morfologia do trabalho, marcada pelo fim da era industrial e reorganização da produção de forma automatizada. O capital busca outros modos para se multiplicar, suas cifras agora são digitais, o seu lastro é a especulação. Ao capital não interessam mais as memórias do trabalho e da técnica, está tudo automatizado, a ele interessam apenas as memórias que o valor pode agregar, construindo ou destruindo setores econômicos e produtivos em poucas horas e com poucas, ou muitas, ações migrando de lado a lado no setor especulativo.

\section{Imaginário}

O primeiro livro de Sebastião Salgado intitula-se Outras Américas (1986). Produzidas nos anos 70, as imagens deste

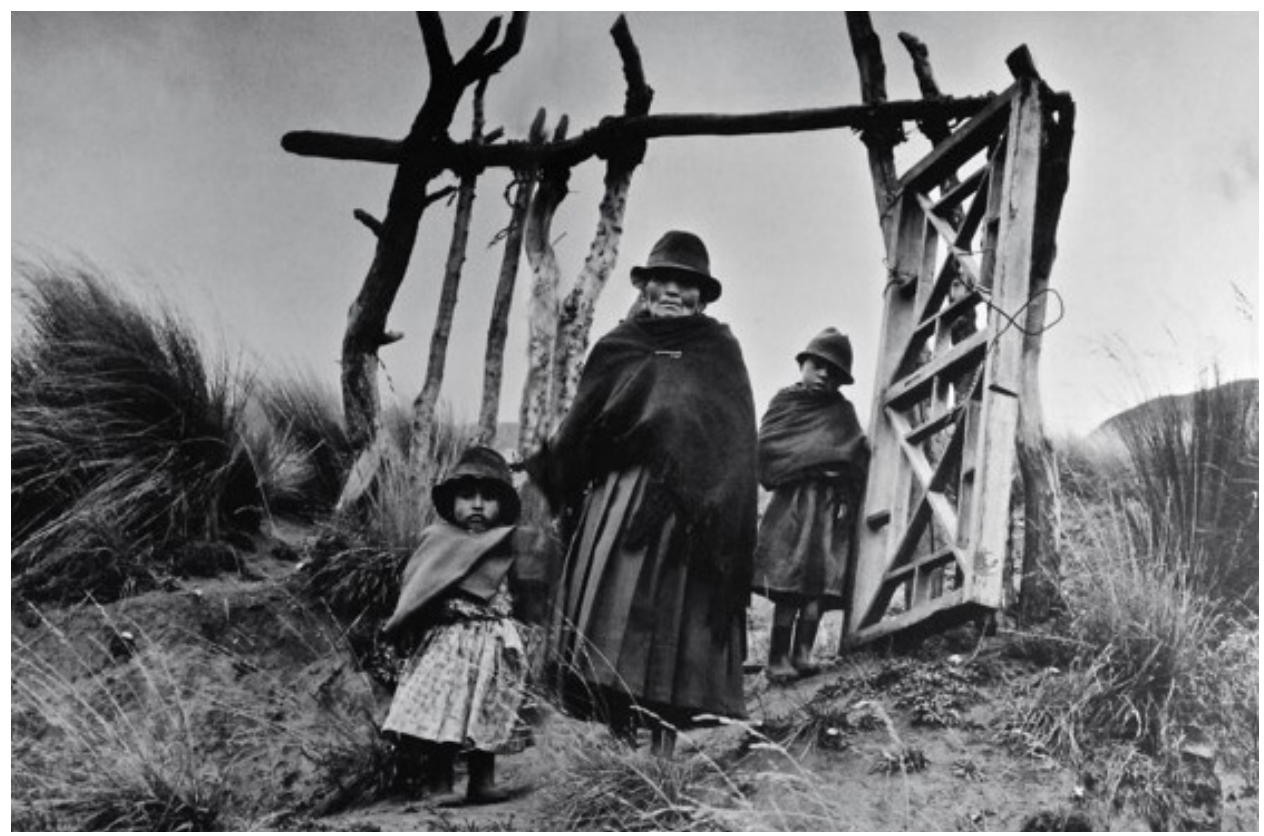

Figura 4. Outras Américas, 1986. Equador, 1982. 
ensaio retratam o processo acelerado de diluição das comunidades rurais de pequenos agricultores organizados com base na agricultura familiar. $\mathrm{O}$ momento histórico marcado no campo peloêxodo rural transformou profundamente a geografia e a sociedade latino-americanas. Os pequenos produtores, perdendo suas terras para a monoprodução automatizada, adensavam a demografia de regiões marginalizadas e sem infraestrutura nas grandes cidades de todos os países da América Latina, atraídos pelo mercado de serviços domésticos e no comércio nos grandes centros. Esta década, fundo histórico de Outras Américas, é ainda marcada pelas ditaduras militares em alguns países latino-americanos, em especial pelo recrudescimento da ditadura no Brasil. O ensaio todo, apesar de não tocar nos pontos nevrálgicos da política e da resistência no campo, assume em sua forma o sentido dos limites políticos do processo social em curso. Salgado documenta as transformações no mundo do trabalho e na distribuição da terra, principal instrumento de poder e meio de produção em todo o continente. Seu olhar contempla a derrota sem luta, suas memórias estetizam a distopia, conciliam com o abismo. As imagens são belas, terrivelmente belas. E nisso assenta uma questão ética complicada, como aponta radicalmente Susan Sontag, no livro Diante da dor dos outros (2004).

A porta aberta, na imagem acima, vista por uma ótica desiludida, acusa a melancolia da derrota e sugere uma saída desprovida de sentido, uma sugestão vazia. Não há paredes ao redor dessa porta, tudo parece igual tanto de um lado como de outro. Vista por outra ótica, esta passagem, feita com um gradeado firme de madeira cujos encaixes desenham uma esquadria desencaixada do contexto, se fixa sobre uma estrutura rústica e frágil e se abre a um céu acinzentado, melancólico. As expressões asfixiantes e a ausência de saída atribuem ao declínio um desconforto e uma perigosa beleza.

O primeiro livro de Sebastião Salgado é estetizado, apesar do tema. É um livro muito bonito e distópico. O olhar do fotógrafo é ainda apressadamente curioso, suas memórias estão maculadas pela revolta de um indivíduo exilado. A forma de Outras Américas é uma fórmula que apenas observa o problema. Não há revolta ou rebelião no seu imaginário. Em Memórias do futuro, André Bueno fala num dilema do processo social e histórico em curso.

Como dar forma à violência e à barbárie sem estetizar a miséria humana, sem fazer da dor dos outros um espetáculo, para lembrar aqui Susan Sontag? Como dar a dimensão dos problemas mais fundos sem folclorizar, reduzir, estetizar, tornar apenas espetáculo e fruição passiva os limites mais difíceis da experiência social? Sem esquecer, desde logo, que a recepção de toda forma estética é inseparável do seu momento de fruição, de prazer associado à forma elaborada do material, mesmo quando se trata da violência e da barbárie. Mas também é verdade que a dimensão estética, ao tratar desses extremos difíceis, pode vir acompanhada de uma dimensão ética, que dê à configuração dignidade e se ponha à altura de seu assunto (BUENO, 2009, p. 24).

Salgado balança, neste livro, entre a tensão indiciada pela imagem e a sua beleza. No ensaio de estreia, Salgado reproduz uma ordem visual passiva que naturaliza o desconforto alheio. Porém, ao longo dos projetos, o fotógrafo reelaborará seu imaginário, como ele mesmo afirma 
no prefácio do livro Êxodos, uma década e meia mais tarde.

A experiência operou profunda mudança em mim. Ao dar início a este projeto, eu estava habituado a trabalhar em condições difíceis. Pensava que minhas convicções políticas ofereciam respostas para um grande número de problemas. Acreditava sinceramente que a humanidade avançava num rumo positivo. Estava despreparado para o que veio a seguir (SALGADO, Exodos, p. 10).

A imagem abaixo (Fig.5) apresenta uma outra porta menos estetizada. Trata-se de um abrigo no território sudanês durante a guerra civil nos anos 90. Estes jovens, ao contrário daqueles de que se falou no início deste texto, não haviam ainda conseguido fugir para campos de refugiados nos países vizinhos, como o Quênia, onde eles frequentariam escolas improvisadas nos abrigos da ONU, como mostra a primeira fotografia comentada. Entretanto, estes jovens não conseguiram se refugiar e escondem-se do estado e das milícias que os capturariam e os forçariam a lutar contra seus irmãos se os encontrassem.

Durante mais de vinte anos, Sebastião Salgado viajou por mais de quarenta países registrando as transformações no mundo do trabalho, representando o chamado fim da era industrial e a sua nova morfologia ideológica, chamada globalização. O resultado disso foi mostrado em três ensaios fotográficos. Nestes livros, no entanto, o fotógrafo revela a falácia desta ideologia. Escondida por trás da face técnica e política do novo arranjo no modo de produção capitalista, a permanência das contradições entre centro e periferia, entre setor industrial e setor de produção de commodities,

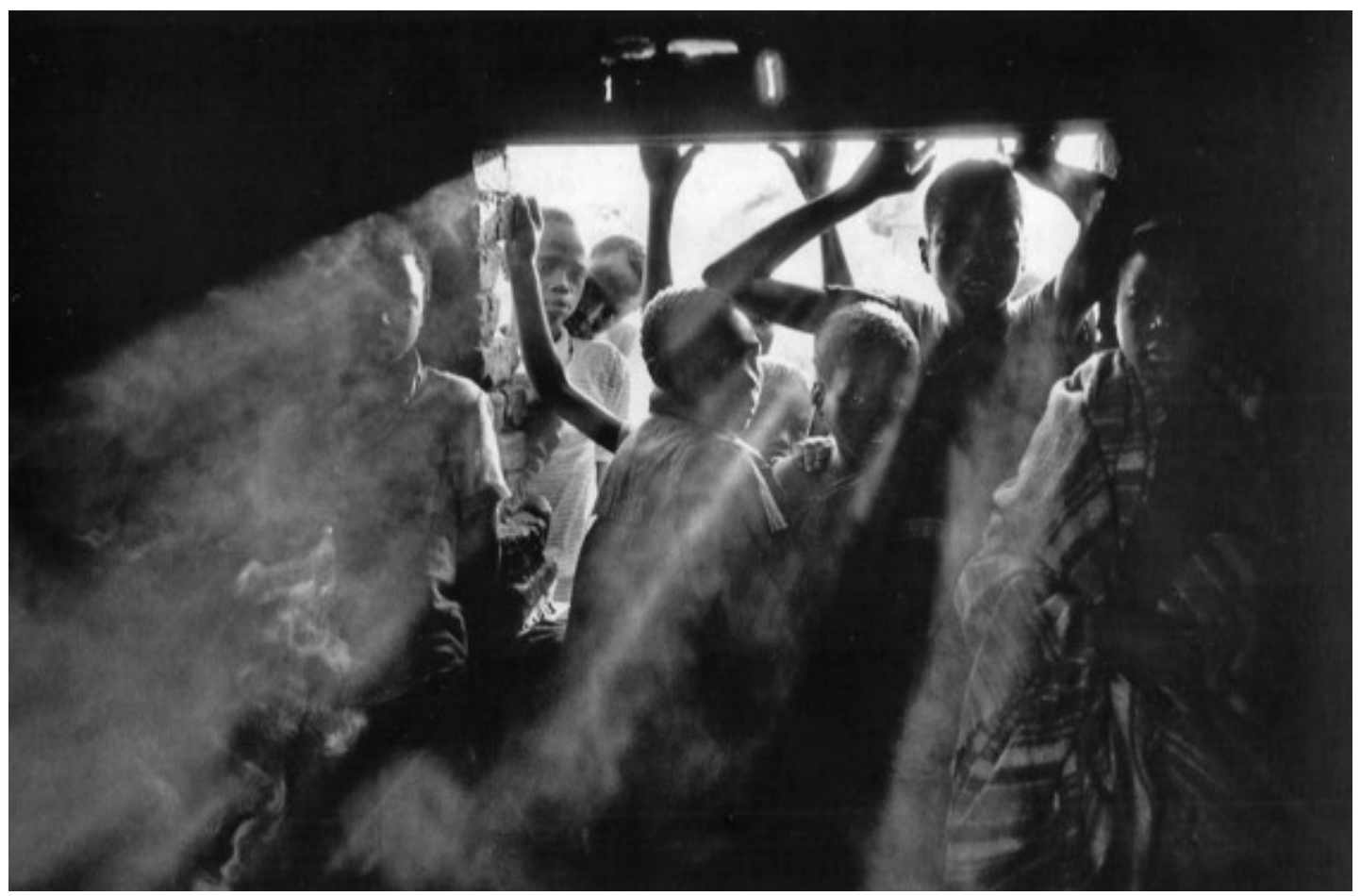

Figura 5. Êxodos, 2000. Abrigo no Sudão do Sul. Guerra Civil no Sudão 1994. 
revela-se no olhar, nas memórias e no imaginário do fotógrafo. As transformações geopolíticas e geoprodutivas mantêm a dialética da colonização e recolonização da periferia. $\mathrm{O}$ autocontraste da imagem acima permite que se formem feixes de luz que cortam a fotografia em diagonal. Como facas, representando a guerra doméstica, tais feixes atravessam simbolicamente estes meninos paralisados. O ponto de fuga indica a porta iluminada do abrigo à qual os personagens da composição viram as costas. Tragicamente impedidos de sair, seus terríveis olhares, através da lente do fotógrafo, cruzam suas memórias, interferem em seu imaginário e se dirigem a nós, cobrando uma saída verdadeira para o terror que vivem.

Salgado experimentou nestes olhares o surgimento de uma dúvida: se o processo de transformação do trabalho e da exploração do capital impõe uma mobilização populacional ao mesmo tempo no planeta, não há movimentos de resistência? Daí surgirá o projeto de construção de um livro dedicado à luta dos trabalhadores sem terra no Brasil.

Muito distante da idealização do primeiro ensaio, o livro Êxodos é uma síntese das transformações operadas no planeta a partir da nova morfologia do trabalho na era pós-industrial. A imagem estetizada da violência imposta à periferia do capital pelo arranjo dos interesses hegemônicos se transforma numa imaginação afirmativa da resistência e pela emancipação. A sugestão se dá na fotografia da ocupação de uma área rural improdutiva no sul do Brasil pelo Movimento dos Trabalhadores sem Terra - MST (Fig. 6).

A cerca que se estende para além do portão e o forte alicerce em que

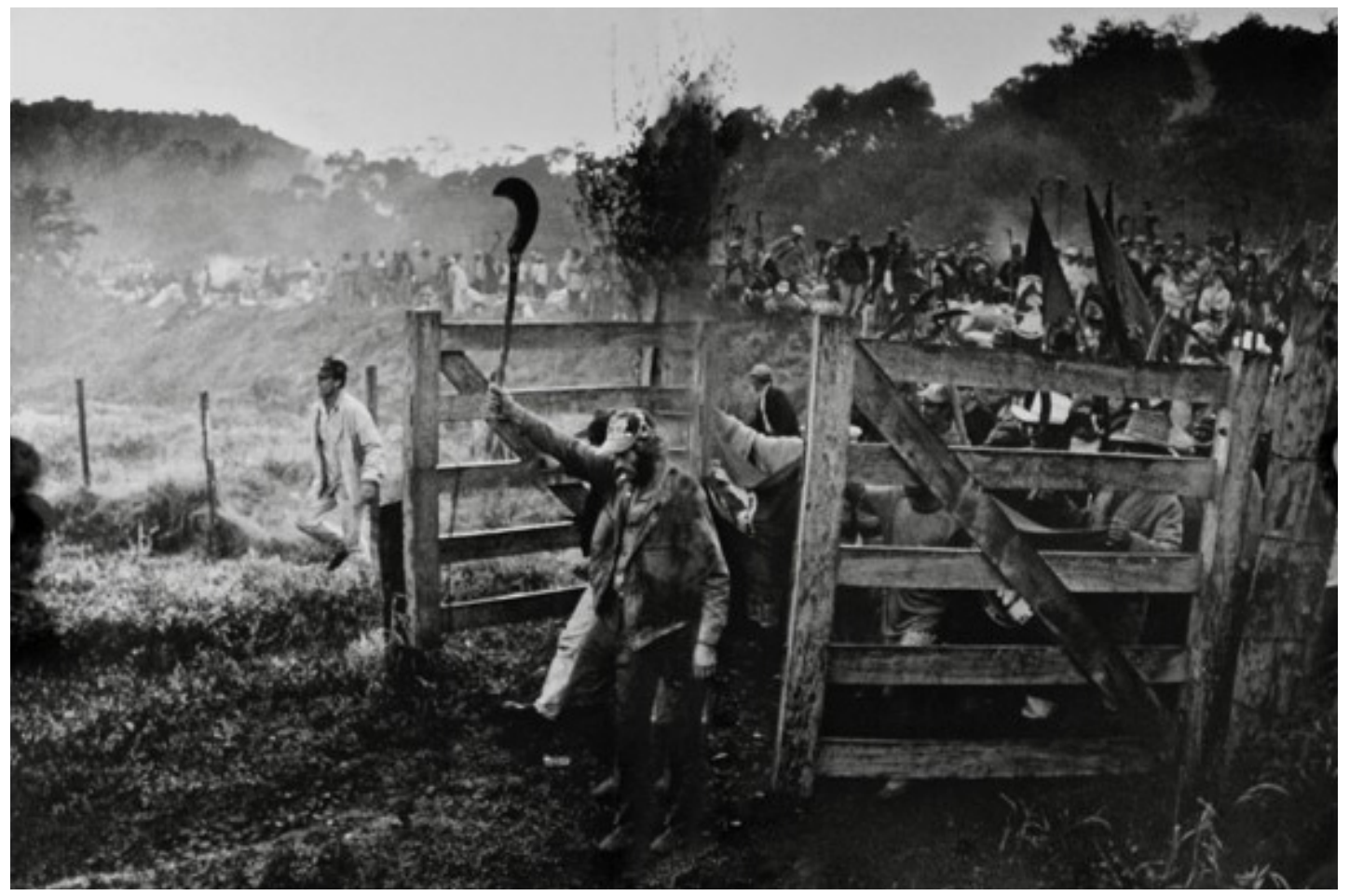

Figura 6. Êxodos, 2000. MST ocupa fazenda improdutiva no Paraná, 1996. 
toda a estrutura se equilibra contrastam radicalmente com a fotografia analisada de Outras Américas. As imagens do MST neste ensaio foram realizadas no final dos anos 90. Homens com ferramentas para lavrar a terra, bandeiras e mãos erguidas abrem a porteira e ocupam a Fazenda Giacometti, latifúndio improdutivo de exploradores madeireiros do Sul. A fazenda, desapropriada pelo Ministério da Reforma Agrária, no início da década de 80, ainda estava em posse dos madeireiros graças ao arquivamento do processo, motivado pela proximidade do grupo com o governo do estado do Paraná.

A imagem sugere e incita a resistência e a luta no campo. O ângulo em que ela foi tomada deixa entrever a coluna de pessoas que se perde na sua profundidade, ressaltando a força e a coerência do movimento, legitimado em suas diversas bandeiras. Aqueles que estão fora da propriedade privada, irrompem na direção do espaço daqueles que os veem como intrusos. Eles abrem a porteira da propriedade de fora para dentro, na direção confortável, aliás, em que nós, espectadores, os vemos entrar. À frente, um homem com sua foice erguida simboliza a vanguarda e a liderança. Símbolo clássico na representação das lutas dos trabalhadores rurais pela apropriação da sua força de trabalho, a foice funciona como uma espécie de guia à coluna que a segue.

Todo o ensaio parece convergir em direção a uma saída para aquele emaranhado. Essa saída não é a fuga individual, mas a concentração de energia para uma luta coletiva contra o processo intenso de desagregação no campo. A fotografia, além de evidenciar, tornar pública e reafirmar a luta do MST, reverbera a voz dos milhares de trabalhadores reunidos para resistir. A resistência ganha o apelo épico na legenda da fotografia dos trabalhadores rurais rompendo a porteira da fazenda.

Era impressionante a coluna dos semterra formada por mais de $12 \mathrm{mil}$ pessoas, ou seja, 3 mil famílias, em marcha na noite fria daquele início de inverno no Paraná. O exército de camponeses avançava em silêncio quase completo. Escutava-se apenas o arfar regular de peitos acostumados a grandes esforços e o ruído surdo dos pés que tocavam o asfalto.

[...]

Anda rápido um camponês: 22 quilômetros foram cobertos em menos de cinco horas. Quando chegaram lá, o dia começava a nascer. A madrugada estava envolta em espessa serração que, pouco a pouco, foi se deslocando da terra, sob o efeito da umidade do rio Iguaçu, que corre ali bem próximo. Pois o rio de camponeses que correu pelo asfalto noite adentro, ao desembocar defronte da porteira da fazenda, para e se espalha como as águas de uma barragem. As crianças e as mulheres são logo afastadas para o fundo da represa humana, enquanto os homens tomam posição bem na frente da linha imaginária para o eventual confronto com os jagunços da fazenda.

Ante a insistência de reação por parte do pequeno exército do latifúndio, os homens da vanguarda arrebentam o cadeado e a porteira se escancara; atrás, o rio de camponeses se põe novamente em movimento; foices, enxadas e bandeiras se erguem na avalanche incontida das esperanças nesse reencontro com a vida - e o grito reprimido do povo sem-terra ecoa uníssono na claridade do novo dia: "REFORMA AGRÁRIA, UMA LUTA DE TODOS!" (ÊXodos, p. 43).

As fotografias que sugerem travessia não têm aqui a mesma poética contemplativa 
do primeiro livro. Se em Outras Américas a travessia é conciliadora, em Êxodos a travessia é a força que move a possibilidade de transformação numa realidade marcada pela combinação de concentração de riquezas e inanição da classe trabalhadora. A travessia em Outras Américas sugere a impotência, o embotamento, o conformismo; a mesma síntese formal no ensaio de 2000, por outro lado, provoca e promove o enfrentamento. Entre os dois ensaios, o olhar, as memórias e o imaginário de Sebastião Salgado são transformados pelo seu trabalho como pesquisador e fotógrafo, pela sua experiência dialetizada, relacionando pontos de vista distintos do mesmo processo: a renovação da hegemonia capitalista, ou a nova morfologia do capital, como é definido o contexto pelo economista Ricardo Antunes. A transformação das imagens de Sebastião Salgado remete a uma transformação pessoal que ele próprio reconhece e que chamamos de sentimento de travessia. Ao mergulhar nas imagens do fotógrafo de maneira ativa, buscando desconstruir suas tensões tecnicamente forjadas por argumentos históricos e dialéticos, também transformamos nosso olhar, nossa memória e nosso imaginário para os problemas de ontem e de hoje. Retomando Bracher, na epígrafe, "a nossa imagem no mundo é a soma dos rumores, dos passos que demos e dos que não andamos, passaram por nós. Não há álibi nem conserto para a história que fica sendo nossa."

\section{Referências}

ANTUNES, Ricardo. Os sentidos do trabalho: ensaios sobre a afirmação e a negação do trabalho. 10. ed. rev. e aum. São Paulo: Boitempo, 2009.

Adeus ao trabalho? Ensaio sobre as metamorfoses e a centralidade do mundo do trabalho. 13. ed. rev. e aum. São Paulo: Cortez, 2008.

BENJAMIN, W. Magia e técnica, arte e política. São Paulo: Brasiliense, 1985. Vol. 1.

BUENO, André. Memórias do futuro. Rio de Janeiro: 7Letras, 2009. p. 24.

SALGADO, Sebastião. Êxodos. Projeto Gráfico: Lélia Wanick Salgado. São Paulo: Cia. das Letras, 2000.

. Outras Américas. Prefácio de Alan Riding. $\overline{\text { Projeto }}$ Gráfico de Lélia Wanick Salgado. São Paulo: Cia das Letras, 1999.

- Terra. Introdução de José Saramago. Versos e canções de Chico Buarque. São Paulo: Cia. das Letras, 1997.

. Trabalhadores: uma arqueologia da era industrial. Introdução de Sebastião Salgado e Eric Nepomuceno. São Paulo: Cia. das Letras, 1996.

SONTAG, Susan. Sobre fotografia. Trad. Rubens Figueiredo. São Paulo: Cia. das Letras, 1973.

. Diante da dor dos outros. Trad. Rubens Figueiredo. São Paulo: Cia. das Letras, 2003.

Recebido: 9 de julho de 2017.

Aceite: 10 de novembro de 2017. 